\title{
Effect of temperature on viability of human hydatid cyst \& study the volume of hydatid cyst
}

\author{
Ismail Abdel-wahabAl-Hadithi *
}

\author{
Maisam Balasm AL-Khamesi**
}

Received 1, December, 2008

Accepted 1, July, 2009

\begin{abstract}
:
The hydatid materials were collected and studied, so they were contained 50 fertile human hydatid cases $\{33(66 \%)$ females and $17(34 \%)$ males $\}$. They were collected from Al-Ramadi General Hospital during the period from December, 2003 to July, 2004 .Cysts were observed in $40(80 \%)$ from the liver, $5(10 \%)$ from the lungs, $3(6 \%)$ from the kidney and $2(4 \%)$ cysts from urinary bladder. The specimens were taken from patients of different ages.

The in vitro viability of protoscoleces was assessed on the basis of flame cell activity and eosein exclusion, which were considered as criteria to determine the death or viability of protoscoleces. In addition to this movement (flame cell activity), another motility like constriction - relaxation (invagination - evagination) in the protoscoleces was also noticed. Both types of movement were examined under light microscope.

The motility of protoscoleces examined under effect of three different temperature degrees $25^{\circ} \mathrm{C}, 37^{\circ} \mathrm{C}$, and $40^{\circ} \mathrm{C}$ was within 15 minutes. It showed steadily increase with rising temperature. Flame cell activity increased as high as $70.01 \%$ at $40^{\circ} \mathrm{C}$, while the motility with constriction -relaxation movement increased as $100.0 \%$ at $40^{\circ} \mathrm{C}$.

The volumes of hydatid cysts were also studied, so they were measured. Therefore, the volumes of human hydatid cysts were the highest in the lung and this is may be due to the spongy texture of the lung tissues. There is relationship between the volumes of Hydatid cysts and the viability was recorded.
\end{abstract}

Key words: Temperature, Viability, Hydatid cyst, Volume.

\section{Introduction:}

Hydatid disease was important public health problem [1,2] .It is a parasitic infection caused by larval stage of Echinococcus granulosus $[3,4]$.

Hydatidosis is potentially dangerous depending on the location of the cyst. Some cysts may remain undetectable for many years until they become large enough to affect other organs [5,6].It is well known that, the protoscolex of Echinococcus granulosus is central in the biological cycle of that parasite and it is of particular interest in primary and secondary infection $[7,8]$.

There are many studies that used various methods for detecting the fertility and assessing the viability of hydatid cysts [9]. Information relative to agree of fertility and viability were taken from important intermediate hosts, have many clinical and epidemiological applications and it should be considered in many program to control and eradicate the disease [10,11].

The aims of the study is to evaluate ,in vitro, the viability and motility of protoscoleses with three degrees of temperature $\left(25^{\circ} \mathrm{C}, 37^{\circ} \mathrm{C}\right.$ and $\left.40^{\circ} \mathrm{C}\right)$, in addition to calculate the volumes of hydatid cysts and study the

* Department of Applied science, Biochemical technology, University of technology, Baghdad, Iraq.

** College of science for women, Baghdad University, Baghdad, Iraq 
relationship between the volumes of hydatid cysts and their viability .

\section{Materials and methods:}

A total of 50 fertile hydatid cysts were obtained from 33 females and 17 males from Ramadi general hospital during the periods from December 2003 to July 2004 .The specimens were taken from different ages and site of infection 40 liver, 5 lung ,3 kidney and 2 urinary bladder.

Hydatid materials which include fluid and cysts whether intact or ruptured were transported as soon as possible to the medical parasitology lab.

Viability of cysts was determined by two methods:

1. Flame cell activity was the activity produced afaint flickering movement [12] by flame propulsion which had led to the use of flickering movement as criterion in assessing the rate of activity .The motility of protoscoleces calculated as flame activity from one point to another and then return to the same point .

In this motility the flame cell completed one cycle. In addition to this movement the protoscoleces might be motile in constriction (invagination) and relaxation (evagination).

2. Vital stain $0.1 \%$ eosin, if protoscoleces exclude eosin that would mean they were viable, where as non viable take up this stain [14].

Determination of the effect of temperature on the motility was also studied at $25^{\circ} \mathrm{C}, 37^{\circ} \mathrm{C}$ and $40^{\circ} \mathrm{C}$ at intervals of 1,2 and 3 minutes after leaving the protoscoleces at 15 minutes in the water bath.

The volume of human hydatid cysts was measured mathematically as Volume $=4 / 3 \times 22 / 7$ ( Radius)^^ .

\section{Results and Discussion:}

Patients were distributed into33(66\%) females and $17(34 \%)$ males , under 20 years of age constituted $18 \%$ while those of 40 years of age and older constituted $34 \%$. (Table 1). Majority $(80 \%)$ of hydatid cysts were removed from liver, the other cases of lung, kidney and bladder $(20 \%)$.

The median cysts volume was the highest in the lung $\left(267.27 \mathrm{~cm}^{\wedge} 3\right)$ followed by hepatic cysts $(22 ., 38) \mathrm{cm}^{\wedge} 3$, kidney $\left(8.15 \mathrm{~cm}^{\wedge} 3\right)$ and bladder $\left(6.16 \mathrm{~cm}^{\wedge} 3\right)$. (Table 2$)$.

Only 15 out of the 50 cases examined $(30 \%)$ showed signs of motility of protoscoleces. The magnitude of biological activity of protoscoleces in these cases was presented by the proportion of protoscoleces with flame activity or constriction - relaxation movement [10].

The median of percent protoscoleces with flame activity increased from $3 \%$ at $25^{\circ} \mathrm{c}$ to $38.9 \%$ at $37^{\circ} \mathrm{c}$ and finally as high as $70.1 \%$ at $40^{\circ} \mathrm{c}$ (Table 3 ).

Protoscoleces with constriction relaxation movement increased from $1.3 \%$ at $25^{\circ} \mathrm{c}$ to $50.9 \%$ at $37^{\circ} \mathrm{c}$ and finally to $100.0 \%$ at $40^{\circ} \mathrm{c}$ (Table 4 ). Both kinds of motility showed obvious trend with rising temperature.

Our study showed that two kinds of motility of protoscoleces were submitted to 3 different temperatures, flame cell activity and constriction relaxation movements are documented.

Our result showed that both kinds of motility showed an obvious positive trend with rising temperature, for this reason, increased temperature to $25^{\circ} \mathrm{C}$ like $37^{\circ} \mathrm{C}$ and $40^{\circ} \mathrm{C}$ caused increased stimulation of the flame cell activity of the protoscoleces and more increase of the stimulation of constriction relaxation activity .Therefore ,the motility of protoscoleces in flame activity may reach to $70.1 \%$ at $40^{\circ} \mathrm{C}$ 
,while another motility of protoscolecses(constriction-relaxation ) movement may reach to $(100 \%)$ at the same temperature .In addition, in cases with no kind of motility, the presence of temperature does not effect protoscoleces motility. This result was similar to [10].

The development of hydatid cysts is slow and it needs long time to grow. Cyst size varies usually between 1 to $15 \mathrm{~cm}$ in diameter. Furtherly, lung cysts hardly compress surrounding tissue. Thus, they develop a thin pericyst capsule, and can rapidly become larger, and are more prone to spontaneous rupture. In addition, small cysts $(4 \mathrm{~cm})$ are removed intact if there is little risk of rupture $[15,16]$.

Beside, the volumes of hydatid cysts in this study showed, variance in size depending upon cysts location .Therefore, in some areas of the body they would be unable to expand freely due to the nature of tissues such as liver and kidney, while in others like the lung, they grew and increased in size freely due to the spongy texture of the lung tissues. There was no relationship between the volumes of hydatid cysts and presence of viability of these cysts.

Table 1: Frequency distribution of the study samples by Sociodemographic variables.

\begin{tabular}{|c|c|lr|}
\hline$\%$ & $\mathrm{~N}$ & \\
\hline & & & \\
\hline $\mathbf{6 6}$ & $\mathbf{3 3}$ & Female & \\
\hline $\mathbf{3 4}$ & $\mathbf{1 7}$ & Male & \\
\hline \multicolumn{2}{|l|}{ Age in years } \\
$\begin{array}{l}\text { <20 } \\
20-39\end{array}$ & $\mathbf{9}$ & $\mathbf{1 8}$ \\
\hline $\mathbf{3 4}$ & $\mathbf{1 7}$ & $40+$ & $\mathbf{4 8}$ \\
\hline $\mathbf{1 0 0}$ & $\mathbf{5 0}$ & Total \\
\hline
\end{tabular}

Table 2: The difference in median volume of surgically removed Hydatid cysts by their site .

\begin{tabular}{|c|c|c|c|}
\hline & $\begin{array}{c}\text { Longest } \\
\text { diameter of the } \\
\text { cyst }(\mathrm{cm})\end{array}$ & $\begin{array}{c}\text { Smallest } \\
\text { diameter of } \\
\text { the cyst }(\mathrm{cm})\end{array}$ & Cyst volume $(\mathrm{cm} 3)$ \\
\hline \multicolumn{4}{|l|}{ Liver } \\
\hline Range & $(1$ - 15) & $(0.5$ - 14.5) & $(0.52-1761.83)$ \\
\hline Median & 3.5 & 3 & 22.38 \\
\hline Number & 40 & 40 & 40 \\
\hline \multicolumn{4}{|l|}{ Lung } \\
\hline Range & $(4.5-10)$ & $(4-9.5)$ & $(47.56-522.02)$ \\
\hline Median & 8 & 7.5 & 267.27 \\
\hline Number & 5 & 5 & 5 \\
\hline \multicolumn{4}{|l|}{ Kidney } \\
\hline Range & $(1.4-15)$ & $(1-14)$ & $(1.43-1761.83)$ \\
\hline Median & 2.5 & 2 & 8.15 \\
\hline Number & 3 & 3 & 3 \\
\hline \multicolumn{4}{|l|}{ Bladder } \\
\hline Range & $(1.5-14.5)$ & $(1$ - 14) & $(1.67-1591.45)$ \\
\hline Median & 2.3 & 1.8 & 6.16 \\
\hline Number & 2 & 2 & 2 \\
\hline
\end{tabular}

Table 3: The change in median of percent protoscoleces with flame activity with rising temperature among samples with at least one active protoscolicies at baseline (25 C).

\begin{tabular}{|l|c|c|c|}
\hline \multicolumn{4}{|c|}{ Percent protoscoleces with flame activity } \\
\hline & $40^{\circ} \mathrm{C}$ & $37^{\circ} \mathrm{C}$ & $25^{\circ} \mathrm{C}$ \\
\hline Range & $\mathbf{( 1 6 - 8 8 . 2 )}$ & $\mathbf{( 2 8}-\mathbf{4 9 . 2})$ & $\mathbf{( 0 . 9}-\mathbf{9 . 8})$ \\
\hline Median & $\mathbf{7 0 . 1}$ & $\mathbf{3 8 . 9}$ & $\mathbf{3}$ \\
\hline $\mathrm{N}$ & $\mathbf{1 5}$ & $\mathbf{1 5}$ & $\mathbf{1 5}$ \\
\hline
\end{tabular}

Table 4: The change in median of percent protoscoleces with constriction-relaxation movement with rising temperature among samples with at least one active protoscoleces at baseline $\left(25{ }^{\circ} \mathrm{C}\right)$.

\begin{tabular}{|l|c|c|c|}
\multicolumn{4}{|c|}{ Percent protoscoleces with constriction-relaxation } \\
movement
\end{tabular}

\section{References:}

1-Mahmoud,S.S 1980. Studies on hydatid disease in Mosul. M.Sc. Thesis. College of Science. University of Mosul, Iraq.

2-Mahmoud S.S. and Al-Janabi, B. M. 1983. Hydatid disease in children and youths in Mosul, Iraq .Ann. Trop .Med .parasitol. , 77:237-238. 
3-Paniker, J. 2002. Text book of Medical parasitology. $5^{\text {th }}$ ed. Jaypee Brothers Medical Publishers. New Delhi.

4-Eckert, J., Conraths, F., \& Tackmann, K. 2000. Echinococcosis: an emerging or reemerging zoonosis. Int. J. parasitol., 30: 1283-1294.

5-Schimdt, G. D. \& Roberts, L. S. 2000. Foundations of parasitology. (Eds. Roberts, L. S. \& Janory, J.). $6^{\text {th }}$ ed. McGraw-Hill International Editions.

6- Salinas, J. C., Torcal, J., Lozano, R., Sousa, R., Morandeira, A. \& Cabezali, R. 2000. Intracystic infection of liver hydatidosis. Hepatogastroenterology., 47: 10521055.

7- Pawlowski, Z. S., Eskert, J. \& Vutiion, D. A. 2001. Echiniciccosis in humans: clinical aspects, diagnosis \& treatment. (Ed. Eskert, J.). WHO/OLE. Manual on echonococcosis in humans \& animals. WHO/OLE., 20-71

8- Kabra, V. Shrma, O. P. Agarwal, M. and Shukla, V. K. 2001. Primary hepatic hydatid cyst with intrathoracic extension. J. Indian Med. Assoc., 99 : 331-334.

9- Campos, B. A., Lopez, A. G. \&
Andres, C. A.2000. Risk factors for Echinococcus granulosus infection : a case-control study. Am. J. Trop. Med. Hyg., 62:329-334.

10- Al-Autabbi, R. 1983. Fertility and viability of hydatid cysts in some intermediate hosts in Iraq .M.Sc. Thesis . College of Medicine University of Baghdad ,Iraq.

11-Zmerli, S., Ayed, M. \& Horchani, A. 2001. Hydatid cyst of the kidney: diagnosis \& treatment. World J. surg., 25: 68-74.

12- Smyth, D.D. and Barret ,N. J. 1980. Procedures for testing the viability of human hydatid cysts following surgical removal , especially after chemotherapy .Trans .Roy .Soc. Trop .Med .Hyg., 74:649-652.

13- Macpherson, C. L. 1983. An active intermediate host role for man in the life cycle of Echinococcus granulosus in Turkana. Kenya. Am. J. Trop. Med. Hyg., 32 : 397 404.

14- Ramos, G., Orduna, A. \& GarciaUst, M. 2001. Diagnosis \& treatment. In: Hydatid cyst of the lung. World J. surg., 25:46-57.

15- Safioleas, M., Misiakos, E. P. and Dosios, T. 1999. Surgical treatment for lung hydatid disease. World J. Surg., 23: 1181-1182. 


\section{تأثيردرجة الحرارة في حيوية الأكياس المائية في الإنسان ودراسة حجوم الأكياس المائية}

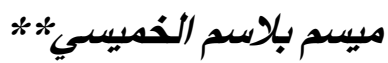

أسعاعيل عبدالوهاب الحليثيث

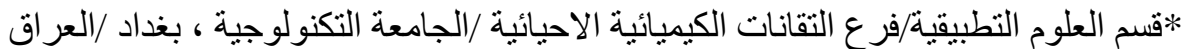

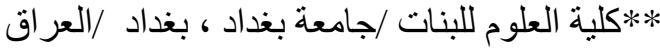

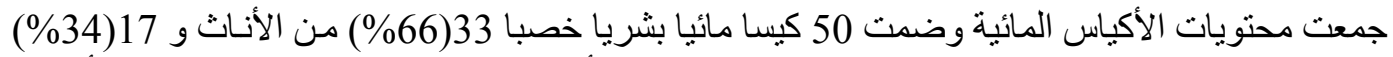

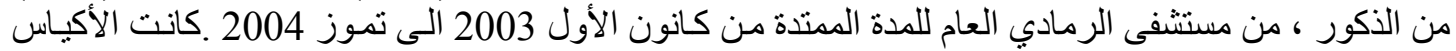

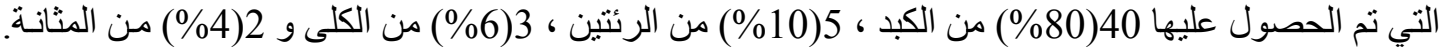
اخذت العينات من مرضى عالتهأ العمار مختلفة.

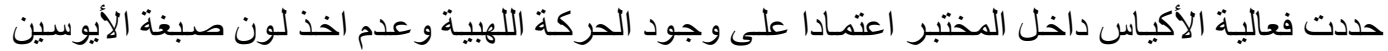

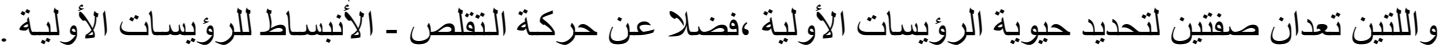

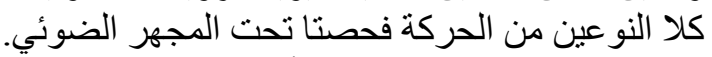

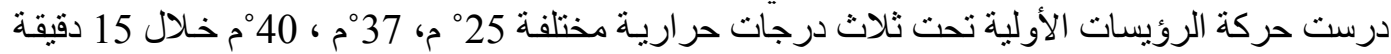

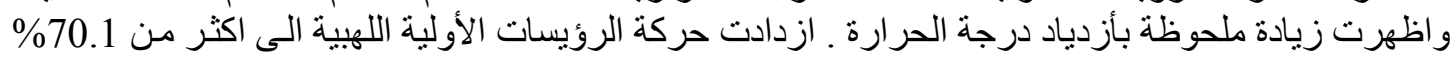

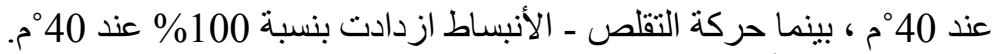

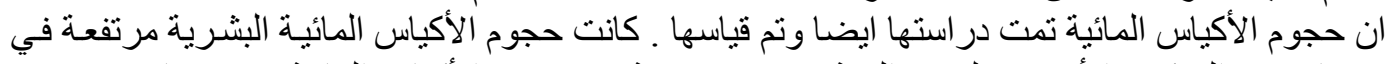
الرئة ربما بسبب التركيب الأسفنجي لنسيج الرئة ـ لاتوجد علاقة بين حجوم الأكياس المائية وحيويتها. 